Published in final edited form as:

Curr Opin Pharmacol. 2006 April ; 6(2): 130-135.

\title{
Role of HMGB1 in cardiovascular diseases
}

\author{
Wei Li ${ }^{1,2}$, Andrew E Sama ${ }^{1}$, and Haichao Wang ${ }^{1,2}$ \\ 1 Department of Emergency Medicine, North Shore University Hospital, New York University School \\ of Medicine, 350 Community Drive, Manhasset, NY 11030, USA \\ 2 Center for Immunology \& Inflammation, Feinstein Institute for Medical Research, Manhasset, New \\ York 11030, USA
}

\section{Abstract}

A nuclear protein, high mobility group box 1 (HMGB1), is released passively by necrotic cells, and actively by macrophages/monocytes in response to exogenous and endogenous inflammatory stimuli. After binding to the receptor for advanced glycation end products (RAGE) or toll-like receptor 4 (TLR4), HMGB1 activates vascular endothelial cells and macrophages/monocytes to express proinflammatory cytokines, chemokines and adhesion molecules. Pharmacological suppression of its activities or release is protective against lethal endotoxemia and sepsis, establishing HMGB1 as a critical mediator of lethal systemic inflammation. In light of the pathogenic role of inflammation in cardiovascular diseases, we propose that HMGB1, a proinflammatory cytokine derived from both injured endothelium and activated macrophages/monocytes, could contribute to the progression of atherosclerosis and other cardiovascular diseases.

\section{Introduction}

Approximately 30 years ago, a non-histone nucleosomal protein was purified from nuclei and termed 'high mobility group 1' (HMG-1) (or high mobility group box 1, HMGB1) based on its rapid mobility on electrophoresis gels [1••]. It is constitutively expressed in quiescent cells, and a large 'pool' of preformed HMGB1 is stored in the nucleus [2] as a result of the presence of two lysine-rich nuclear localization sequences [3]. HMGB1 is among the most evolutionarily conserved proteins in eukaryotes: it shares $100 \%$ identity in amino acid sequence between mouse and rat, and a 99\% amino acid identity between rodent and human [1••].

HMGB1 contains a continuous stretch of negatively charged (aspartic and glutamic acid) residues in the $\mathrm{C}$-terminus, and two internal repeats of positively charged domains ('HMG boxes' known as 'A box' and 'B box') in the N-terminus (Figure 1). As a non-histone chromosomal protein, HMGB1 has been implicated in diverse cellular functions, including determination of nucleosomal structure and stability, and binding of transcription factors to their cognate DNA sequences [4••]. In addition to the nucleus, HMGB1 is also localized to the cell membrane of neuronal (neuroblastoma) cells, where it co-localizes and interacts with the receptor for advanced glycation end products (RAGE) [5••]. Recently, we discovered that HMGB1 is released by activated macrophages/monocytes, and functions as a late mediator of lethal endotoxemia and sepsis $[1 \bullet \bullet, 6-8]$. The recent discovery of HMGB 1 as a critical mediator of inflammation diseases has stimulated tremendous interest in the field of inflammation research. In this article, we provide an overview of recent advances in uncovering its extracellular role as a proinflammatory cytokine, and discuss its potential roles in cardiovascular diseases. 


\section{Release of HMGB1 - who let the dog out?}

Quiescent macrophages/monocytes constitutively express HMGB1, and maintain an intracellular 'pool' of HMGB1 predominantly in the nucleus [2]. Following stimulation with exogenous bacterial products (such as endotoxin) or endogenous proinflammatory cytokines (such as tumor necrosis factor [TNF], interleukin [IL]-1 $\beta$, interferon [IFN]- $\gamma$ ), cultures of macrophages, monocytes and pituicytes actively release HMGB1 in a time- and dosedependent manner [6,9-11]. HMGB1 release induced by endotoxin initiates several hours after the insults, distinguishing itself from early proinflammatory cytokines. Because its $\mathrm{N}$-terminus lacks a signal sequence, HMGB1 cannot be released via the classical endoplasmic reticulumGolgi secretory pathway. Instead, activated macrophages/monocytes acetylate HMGB1 at potential nuclear localization sequences, leading to its cytoplasmic translocation and subsequent release into the extracellular milieu [2,3,10-12].

In addition to its active release from innate immune cells, HMGB1 can also be released passively from necrotic or damaged cells [13,14]. HMGB1 released by necrotic cells is capable of inducing an inflammatory response, thereby transmitting the 'injury' signal to neighboring immune cells [13]. However, HMGB1 is not released by apoptotic cells [13], which disintegrate themselves without setting off an inflammatory response. Therefore, HMGB1 might be a critical molecule that allows innate immune cells to respond to both infection and injury, thereby triggering a rigorous inflammatory response. In contrast to its delayed release after endotoxemia and microbial infection [6,7], HMGB1 is released quickly after tissue ischemia/ reperfusion injury [15], thereby functioning as an early inflammatory mediator of tissue injury.

The kinetics of HMGB1 accumulation in vivo has been studied in murine models of endotoxemia and sepsis (induced by cecal ligation and puncture [CLP]). Serum HMGB1 was first detectable eight hours after the onset of lethal endotoxemia and experimental sepsis, increased to plateau levels from 16 to 32 hours, and remained elevated for at least 72 hours [6,7]. The late appearance of HMGB1 parallels with the onset of animal lethality from endotoxemia or sepsis, and distinguishes itself from TNF and other early proinflammatory cytokines [16]. In septic patients, serum HMGB1 levels are elevated [6,17], and are significantly higher in septic patients who did not survive compared with HMGB1 levels of survivors [6].

In the absence of infection, other stimuli (e.g. hemorrhagic shock) can also stimulate the systemic release of HMGB1. In an animal model of hemorrhagic shock, tissue HMGB1 levels are significantly increased [18]. Similarly, serum HMGB1 levels increased significantly in a patient with hemorrhagic shock, and returned toward basal levels as the clinical condition improved [19]. The mechanisms of HMGB1 release in the absence of infection remain elusive, but are possibly attributable to active release from immune cells, as well as passive leakage from damaged and dying cells [16].

\section{Binding of HMGB1 to cell surface proteins - where does the dog bite?}

HMGB1 binds to RAGE [5••], a member of the immunoglobulin superfamily of cell surface molecules expressed on mononuclear phagocytes, vascular smoothmuscle cells and neurons [5••]. Engagement of RAGE with ligands (such as AGEs or HMGB1) activates mitogenactivated protein kinase (MAPK) and NF- $\mathrm{\kappa B}[5 \bullet, 20]$, and induces production of various proinflammatory cytokines. The important role of RAGE in HMGB1-induced cytokine production was supported by two observations. First, RAGE-neutralizing antibodies significantly attenuated HMGB1-induced TNF release (between 40 and 50\%) (H Wang, unpublished). Second, depletion of RAGE expression partially attenuated HMGB1-induced production of proinflammatory cytokines [21]. 
Recent structure/functional studies have revealed distinct localization between the cytokine functional motif (amino acids 106-123) in the 'B box' and the RAGE-binding motif (amino acids 150-183) in the C-terminus [22-24], suggesting a potential involvement of other receptors for HMGB1-mediated macrophage activation (Figure 1). Indeed, accumulating evidence has established a role for toll-like receptor 4 (TLR4) as an alternative cell surface receptor for HMGB1 to activate innate immune cells [25]. Consistently, TLR4-defective (C3H/ HeJ) mice are more resistant to HMGB1-mediated ischemic injury [15], supporting an important role for TLR4 in HMGB1-mediated inflammatory responses.

In vitro, HMGB1 stimulates macrophages, monocytes and neutrophils to release proinflammtory cytokines (e.g. TNF, IL-1, IL-6, IL-8 and macrophage inflammatory protein [MIP-1]) in a p38 and JNK MAPK-dependent mechanism [24,26]. Similarly, in response to HMGB1 stimulation, human microvascular endothelial cells increase the expression of intracellular adhesion molecule 1 (ICAM-1), vascular adhesion molecule 1 (VCAM-1), proinflammatory cytokines (e.g. TNF) and chemokines (e.g. IL-8) $[27,28]$, suggesting that HMGB 1 can propagate an inflammatory response in the endothelium during infection or injury.

In vivo, intratracheal administration of HMGB1 induces lung neutrophil infiltration, local production of proinflammatory cytokines (e.g. IL-1 $\beta$ and TNF), and acute lung injury [29-31]. Intracerebroventricular application of HMGB1 induces brain TNF and IL-6 production, and sickness behaviors such as anorexia and taste aversion [32]. Focal administration of HMGB1 near sciatic nerve induces unilateral and bilateral low threshold mechanical allodynia [33]. Finally, intraperitoneal injection of HMGB1 increases ileal mucosal permeability, leading to bacterial translocation to mesenteric lymph nodes [34]. Considered together, these studies indicate that accumulation of HMGB1 can amplify the cytokine cascade, and mediate injurious inflammatory responses.

\section{Suppression of HMGB1 release - the caging of the beast}

The important role of HMGB1 as a late mediator of lethal endotoxemia and sepsis (induced by CLP) has been established using HMGB1-specific neutralizing antibodies. Anti-HMGB1 antibodies dose-dependently protect mice against lethal endotoxemia [6], as well as endotoxininduced acute lung injury [29,31]. Furthermore, anti-HMGB1 antibodies rescue mice from lethal sepsis even when the first dose of antibodies is given as late as 24 hours after CLP surgery [7].

The search for potential therapeutic agents capable of inhibiting HMGB1 release has been fruitful. An increasing number of agents (ethyl pyruvate, stearoyl lysophosphatidylcholine, nicotine) dose-dependently inhibits HMGB1 release, and confers significant protection against lethal sepsis [2,8,35-38]. Neutralizing antibodies against IFN- $\gamma$, a cytokine capable of stimulating HMGB1 release [10], significantly reduced circulating HMGB1 levels in septic rats, and consequently rescued rats from lethal sepsis [39]. Most recently, we discovered that green tea and aqueous extract of a Chinese herb, Angelica sinesis, significantly attenuated endotoxin-induced HMGB1 release [40,41], and rescued mice from lethal sepsis [41]. Notably, these anti-HMGB1 reagents are capable of rescuing animals from lethal sepsis even when the first doses are given 24 hours after onset of sepsis [7,8,35], indicating a wider window for HMGB1-targeted therapeutic strategies.

\section{Potential role of HMGB1 in cardiovascular diseases}

Atherosclerosis is a progressive disease characterized by a gradual buildup of lipid in the artery wall. Originally perceived as a disorder of lipoprotein accumulation, it is now considered as a chronic inflammatory disease of the arterial system. Although endothelial injury and dysfunction remain central to the initiation and pathogenesis of the disease, accumulating 
evidence suggests that inflammation evoked by injury plays a pathogenic role in all stages of the disease, from initiation to plaque rupture and associated thrombotic complications [42, 43]. In light of its cytokine activities, we propose a potential role for HMGB1 in the pathogenesis of atherosclerosis.

\section{Formation of fatty streak}

In response to endothelial cell injury, the invasion into the arterial wall by macrophages is one of the earliest events in atherosclerosis. Vascular injury induces upregulation of endotheliumderived adhesion molecules, such as ICAM-1 and VCAM-1, which mediate the attachment and accumulation of monocytes, macrophages and platelets on the vessel wall $[42,43]$. These immune cells in turn become activated and release proinflammatory cytokines and chemokines. Proinflammatory cytokines propagate the inflammatory response in an autocrine or paracrine manner, whereas chemokines facilitate a persistent influx of monocytes. Consequently, the progressive accumulation of lipid-laden macrophages ultimately leads to the formation of fatty streaks.

Abundantly expressed in vascular endothelial cells [14,44••], HMGB1 can be passively released from injured endothelial cells (Figure 2). Once released, extracellular HMGB1 can stimulate neighboring endothelial cells to express various proinflammatory cytokines (TNF), chemokines (e.g. IL-8, MCP-1), adhesion molecules (e.g. ICAM-1 and VCAM-1), as well as RAGE $[27,28,45]$. These adhesion molecules (i.e. ICAM-1 and VCAM-1) enforce strong attachment of infiltrated macrophages/monocytes to the endothelium, which should in turn further increase the release of HMGB 1 and other cytokines. In agreement with the above hypothesis, a dramatic increase in HMGB1 levels has been observed in atherosclerotic lesions [44••]. In contrast to the increase of HMGB1-stimulating cytokines, there appears to be a concomitant decrease in HMGB1-inhibiotory proteins such as the anticoagulant protein thrombomodulin, which binds and sequesters HMGB1 [46,47]. Reduced expression of this HMGB1-inhibiting protein could adversely contribute to the pathogenesis of atherosclerosis. Thus, HMGB1 might be a critical molecule that allows innate immune cells to respond to endothelial cell injury, thereby triggering a rigorous inflammatory response in the early stage of atherosclerosis.

\section{Formation of intima and thrombus}

The transition from fatty streaks to the formation of intima (focal thickening of the innermost layer of the artery) requires the mobilization of smooth muscles cells. Because HMGB1 can induce chemotaxis of smooth muscle cells [14], it might also contribute to the formation of intima.

At the late stage of atherosclerosis, the intima plaque can be ruptured, which can lead to the formation of thrombus (Figure 2). Dysfunctional endothelial cells lose their intrinsic anticoagulant properties to allow the adherence of platelet to vascular endothelial cells. If activated, platelets can also release HMGB1 [48], and might contribute to the formation of thrombus and progression of atherosclerosis. In addition, macrophages also contribute critically to the rupture of intima plaque, and the subsequent formation of thrombus by releasing plaque-destabilizing factors (such as proteases) and coagulating substances [49]. Consistently, chemical elimination of tissue macrophage (by $\mathrm{GdCl}_{3}$ ) significantly attenuated atherosclerotic lesion [50]. Interestingly, the expression levels for a HMGB1 receptor, RAGE, are significantly upregulated in macrophages of the atherosclerotic lesions [51], and competitive inhibition of RAGE activity using a soluble RAGE prevents the progression of atherosclerotic injury [52, 53]. Together, these observations point to a possible role for HMGB1 in the late stage of atherosclerosis [53]. 


\section{Ischemic injury}

Thrombus formation can cause a sudden termination of blood flow, leading to rapid ischemic injury, as well as injury-elicited inflammatory responses (Figure 2). HMGB1 plays a pathogenic role in ischemic injury, because its circulating levels are increased shortly after ischemia/reperfusion, and its inhibition is protective against ischemic injury [15]. The expression levels of RAGE, TLR2 and TLR4 are increased after myocardium injury [54], which enables HMGB1 to effectively mediate an inflammatory response, consequently facilitating the progression of ischemic injury. Notably, several HMGB1-inhibiting agents (e.g. ethyl pyruvate, green tea and adrenomedulin) can preserve cardiac function after myocardial ischemic or septic insults [55-57], consistent with a pathogenic role of HMGB1 in cardiovascular diseases.

Although excessive HMGB1 may be pathogenic to cardiovascular diseases, low levels of HMGB1 might still be beneficial. For instance, HMGB1 is capable of attracting stem cells [58••], and may be needed for tissue repair and regeneration. Indeed, a recent study demonstrated that HMGB1 facilitates myocardial cell regeneration after cardiac infarction, and consequently improves myocardial function [59]. Therefore, as with other proinflammatory cytokines, there may be protective advantages of extracellular HMGB1 when released at low amounts. It is thus important to pharmacologically attenuate (but not to completely abrogate) HMGB1 release to interfere the progression of various cardiovascular diseases, and facilitate the recovery of cardiovascular functions.

\section{Conclusions}

HMGB1 is released by necrotic cells and activated macrophages/monocytes, and functions as a critical mediator of lethal systemic inflammation. Following primary endothelial cell injury, it may be passively released, and initiates a pronounced inflammatory response driven both by endothelial cells and infiltrated innate immune cells. It is currently unknown if the HMGB1mediated inflammatory response contributes to the pathogenesis of cardiovascular diseases. Further investigation in this area will improve our understanding of the pathophysiology of atherosclerosis, and identify novel therapeutic strategies for atherosclerosis and other inflammatory diseases.

\section{Acknowledgements}

The studies summarized in this review were supported in part by the National Institutes of Health, National Institute of General Medical Science (R01GM063075, R01GM070817, to HW).

\section{References and recommended reading}

Papers of particular interest, published within the annual period of review, have been highlighted as:

- of special interest

•• of outstanding interest

1••. Wang H, Yang H, Tracey KJ. Extracellular role of HMGB1 in inflammation and sepsis. J Intern Med 2004;255:320-331. [PubMed: 14871456]The authors provide a detailed review of the extracellular role of HMGB1 in inflammation as well as lethal systemic inflammatory diseases such as endotoxemia and sepsis.

2. Chen G, Li J, Qiang X, Czura CJ, Ochani M, Ochani K, Ulloa L, Yang H, Tracey KJ, Wang P, et al. Suppression of HMGB1 release by stearoyl lysophosphatidylcholine:an additional mechanism for its therapeutic effects in experimental sepsis. J Lipid Res 2005;46:623-627. [PubMed: 15687351] 
3. Bonaldi T, Talamo F, Scaffidi P, Ferrera D, Porto A, Bachi A, Rubartelli A, Agresti A, Bianchi ME. Monocytic cells hyperacetylate chromatin protein HMGB1 to redirect it towards secretion. EMBO J 2003;22:5551-5560. [PubMed: 14532127]

4••. Muller S, Ronfani L, Bianchi ME. Regulated expression and subcellular localization of HMGB1, a chromatin protein with a cytokine function. J Intern Med 2004;255:332-343. [PubMed: 14871457] The authors provide an excellent review of the subcellular localization of HMGB1 in various types of cells, and discuss how HMGB1 translocation is tightly regulated at a molecular level.

5••. Huttunen HJ, Rauvala H. Amphoterin as an extracellular regulator of cell motility: from discovery to disease. J Intern Med 2004;255:351-366. [PubMed: 14871459]In this review, the authors present a detailed review of the role of amphoterin, a cytoplasmic membrane-bound form of HMGB1, in the regulation of cell migration using cell-surface receptors such as RAGE.

6. Wang H, Bloom O, Zhang M, Vishnubhakat JM, Ombrellino M, Che J, Frazier A, Yang H, Ivanova S, Borovikova L, et al. HMG-1 as a late mediator of endotoxin lethality in mice. Science 1999;285:248251. [PubMed: 10398600]

7. Yang H, Ochani M, Li J, Qiang X, Tanovic M, Harris HE, Susarla SM, Ulloa L, Wang H, DiRaimo $\mathrm{R}$, et al. Reversing established sepsis with antagonists of endogenous high-mobility group box 1 . Proc Natl Acad Sci USA 2004;101:296-301. [PubMed: 14695889]

8. Wang H, Liao H, Ochani M, Justiniani M, Lin X, Yang L, Al Abed Y, Wang H, Metz C, Miller EJ, et al. Cholinergic agonists inhibit HMGB1 release and improve survival in experimental sepsis. Nat Med 2004;10:1216-1221. [PubMed: 15502843]

9. Wang H, Vishnubhakat JM, Bloom O, Zhang M, Ombrellino M, Sama A, Tracey KJ. Proinflammatory cytokines (tumor necrosis factor and interleukin 1) stimulate release of high mobility group protein-1 by pituicytes. Surgery 1999;126:389-392. [PubMed: 10455911]

10. Rendon-Mitchell B, Ochani M, Li J, Han J, Wang H, Yang H, Susarla S, Czura C, Mitchell RA, Chen $\mathrm{G}$, et al. IFN-gamma induces high mobility group box 1 protein release partly through a TNFdependent mechanism. J Immunol 2003;170:3890-3897. [PubMed: 12646658]

11. Chen G, Li J, Ochani M, Rendon-Mitchell B, Qiang X, Susarla S, Ulloa L, Yang H, Fan S, Goyert $\mathrm{SM}$, et al. Bacterial endotoxin stimulates macrophages to release HMGB1 partly through CD14- and TNF-dependent mechanisms. J Leukoc Biol 2004;76:994-1001. [PubMed: 15331624]

12. Gardella S, Andrei C, Ferrera D, Lotti LV, Torrisi MR, Bianchi ME, Rubartelli A. The nuclear protein HMGB1 is secreted by monocytes via a non-classical, vesicle-mediated secretory pathway. EMBO Rep 2002;3:955-1001.

13. Scaffidi P, Misteli T, Bianchi ME. Release of chromatin protein HMGB1 by necrotic cells triggers inflammation. Nature 2002;418:191-195. [PubMed: 12110890]

14. Degryse B, Bonaldi T, Scaffidi P, Muller S, Resnati M, Sanvito F, Arrigoni G, Bianchi ME. The high mobility group (HMG) boxes of the nuclear protein HMG1 induce chemotaxis and cytoskeleton reorganization in rat smooth muscle cells. J Cell Biol 2001;152:1197-1206. [PubMed: 11257120]

15. Tsung A, Sahai R, Tanaka H, Nakao A, Fink MP, Lotze MT, Yang H, Li J, Tracey KJ, Geller DA, Billiar TR. The nuclear factor HMGB1 mediates hepatic injury after murine liver ischemiareperfusion. J Exp Med 2005;201:1135-1143. [PubMed: 15795240]

16. Wang H, Yang H, Czura CJ, Sama AE, Tracey KJ. HMGB1 as a late mediator of lethal systemic inflammation. Am J Respir Crit Care Med 2001;164:1768-1773. [PubMed: 11734424]

17. Sunden-Cullberg J, Norrby-Teglund A, Rouhiainen A, Rauvala H, Herman G, Tracey KJ, Lee ML, Andersson J, Tokics L, Treutiger CJ. Persistent elevation of high mobility group box-1 protein (HMGB1) in patients with severe sepsis and septic shock. Crit Care Med 2005;33:564-573. [PubMed: 15753748]

18. Kim JY, Park JS, Strassheim D, Douglas I, Diaz V, Asehnoune K, Mitra S, Kwak SH, Yamada S, Maruyama I, et al. HMGB1 contributes to the development of acute lung injury after hemorrhage. Am J Physiol Lung Cell Mol Physiol 2005;288:L958-L965. [PubMed: 15640285]

19. Ombrellino M, Wang H, Ajemian MS, Talhouk A, Scher LA, Friedman SG, Tracey KJ. Increased serum concentrations of high-mobility-group protein 1 in haemorrhagic shock [Letter]. Lancet 1999;354:1446-1447. [PubMed: 10543678] 
20. Sappington PL, Yang R, Yang H, Tracey KJ, Delude RL, Fink MP. HMGB1 B box increases the permeability of Caco-2 enterocytic monolayers and impairs intestinal barrier function in mice. Gastroenterology 2002;123:790-802. [PubMed: 12198705]

21. Kokkola R, Andersson A, Mullins G, Ostberg T, Treutiger CJ, Arnold B, Nawroth P, Andersson U, Harris RA, Harris HE. RAGE is the major receptor for the proinflammatory activity of HMGB1 in rodent macrophages. Scand J Immunol 2005;61:1-9. [PubMed: 15644117]

22. Huttunen HJ, Fages C, Kuja-Panula J, Ridley AJ, Rauvala H. Receptor for advanced glycation end products-binding $\mathrm{COOH}$-terminal motif of amphoterin inhibits invasive migration and metastasis. Cancer Res 2002;62:4805-4811. [PubMed: 12183440]

23. Messmer D, Yang H, Telusma G, Knoll F, Li J, Messmer B, Tracey KJ, Chiorazzi N. High mobility group box protein 1: an endogenous signal for dendritic cell maturation and Th1 polarization. $\mathrm{J}$ Immunol 2004;173:307-313. [PubMed: 15210788]

24. Li J, Kokkola R, Tabibzadeh S, Yang R, Ochani M, Qiang X, Harris HE, Czura CJ, Wang H, Ulloa $\mathrm{L}$, et al. Structural basis for the proinflammatory cytokine activity of high mobility group box 1 . Mol Med 2003;9:37-45. [PubMed: 12765338]

25. Park JS, Svetkauskaite D, He Q, Kim JY, Strassheim D, Ishizaka A, Abraham E. Involvement of TLR 2 and TLR 4 in cellular activation by high mobility group box 1 protein (HMGB1). J Biol Chem 2003;279:7370-7377. [PubMed: 14660645]

26. Park JS, Arcaroli J, Yum HK, Yang H, Wang H, Yang KY, Choe KH, Strassheim D, Pitts TM, Tracey $\mathrm{KJ}$, Abraham E. Activation of gene expression in human neutrophils by high mobility group box 1 protein. Am J Physiol Cell Physiol 2003;284:C870-C879. [PubMed: 12620891]

27. Fiuza C, Bustin M, Talwar S, Tropea M, Gerstenberger E, Shelhamer JH, Suffredini AF. Inflammation-promoting activity of HMGB1 on human microvascular endothelial cells. Blood 2003;101:2652-2660. [PubMed: 12456506]

28. Treutiger CJ, Mullins GE, Johansson AS, Rouhiainen A, Rauvala HM, Erlandsson-Harris H, Andersson U, Yang H, Tracey KJ, Andersson J, Palmblad JE. High mobility group 1 B-box mediates activation of human endothelium. J Intern Med 2003;254:375-385. [PubMed: 12974876]

29. Ueno H, Matsuda T, Hashimoto S, Amaya F, Kitamura Y, Tanaka M, Kobayashi A, Maruyama I, Yamada S, Hasegawa N, et al. Contributions of high mobility group box protein in experimental and clinical acute lung injury. Am J Respir Crit Care Med 2004;170:1310-1316. [PubMed: 15374839]

30. Lin X, Yang H, Sakuragi T, Hu M, Mantell LL, Hayashi S, Al Abed Y, Tracey KJ, Ulloa L, Miller EJ. Alpha-chemokine receptor blockade reduces high mobility group box 1 protein-induced lung inflammation and injury and improves survival in sepsis. Am J Physiol Lung Cell Mol Physiol 2005;289:L583-L590. [PubMed: 15937067]

31. Abraham E, Arcaroli J, Carmody A, Wang H, Tracey KJ. HMG-1 as a mediator of acute lung inflammation. J Immunol 2000;165:2950-2954. [PubMed: 10975801]

32. Agnello D, Wang H, Yang H, Tracey KJ, Ghezzi P. HMGB1, a DNA-binding protein with cytokine activity, induces brain TNF and IL-6 production, and mediates anorexia and taste aversion. Cytokine 2002;18:231-236. [PubMed: 12126646]

33. Chacur M, Milligan ED, Gazda LS, Armstrong C, Wang H, Tracey KJ, Maier SF, Watkins LR. A new model of sciatic inflammatory neuritis (SIN): induction of unilateral and bilateral mechanical allodynia following acute unilateral peri-sciatic immune activation in rats. Pain 2001;94:231-244. [PubMed: 11731060]

34. Sappington PL, Yang R, Yang H, Tracey KJ, Delude RL, Fink MP. HMGB1 B box increases the permeability of Caco-2 enterocytic monolayers and causes derangements in intestinal barrier function in mice. Gastroenterology 2002;123:790-802. [PubMed: 12198705]

35. Ulloa L, Ochani M, Yang H, Tanovic M, Halperin D, Yang R, Czura CJ, Fink MP, Tracey KJ. Ethyl pyruvate prevents lethality in mice with established lethal sepsis and systemic inflammation. Proc Natl Acad Sci USA 2002;99:12351-12356. [PubMed: 12209006]

36. Cui X, Wu R, Zhou M, Dong W, Ulloa L, Yang H, Wang H, Tracey KJ, Simms HH, Wang P. Adrenomedullin and its binding protein attenuate the proinflammatory response after hemorrhage. Crit Care Med 2005;33:391-398. [PubMed: 15699844] 
37. Yan JJ, Jung JS, Lee JE, Lee J, Huh SO, Kim HS, Jung KC, Cho JY, Nam JS, Suh HW, et al. Therapeutic effects of lysophosphatidylcholine in experimental sepsis. Nat Med 2004;10:161-167. [PubMed: 14716308]

38. Wang H, Czura CJ, Tracey KJ. Lipid unites disparate syndromes of sepsis. Nat Med 2004;10:124125. [PubMed: 14760415]

39. Yin K, Gribbin E, Wang H. Interferon-gamma inhibition attenuates lethality after cecal ligation and puncture in rats: implication of high mobility group box 1. Shock 2005;24:396-401. [PubMed: 16205327]

40. Chen X, Li W, Wang H. More tea for septic patients? - Green tea suppresses bacterial endotoxininduced HMGB1 release. Med Hypotheses 2006;66:660-663. [PubMed: 16266789]

41. Wang H, Li W, Li J, Rendon-Mitchell B, Ochani M, Ashok M, Yang L, Tracey KJ, Wang P, Sama AE. The aqueous extract of a popular herbal nutrient supplement, Angelica sinensis, protects mice against lethal endotoxemia and sepsis. J Nutr 2006;136:360-365. [PubMed: 16424112]

42. Mehra VC, Ramgolam VS, Bender JR. Cytokines and cardiovascular disease. J Leukoc Biol 2005;78:805-818. [PubMed: 16006537]

43. Paoletti R, Gotto AM Jr, Hajjar DP. Inflammation in atherosclerosis and implications for therapy. Circulation 2004;109:III20-III26. [PubMed: 15198962]

44••. Kalinina N, Agrotis A, Antropova Y, DiVitto G, Kanellakis P, Kostolias G, Ilyinskaya O, Tararak E, Bobik A. Increased expression of the DNA-binding cytokine HMGB1 in human atherosclerotic lesions: role of activated macrophages and cytokines. Arterioscler Thromb Vasc Biol 2004;24:2320-2325. [PubMed: 15374849]This is the first article reporting that HMGB1 expression levels are upregulated in atherosclerotic lesions, providing the first evidence for a potential link between HMGB1 and atherosclerosis.

45. Mullins GE, Sunden-Cullberg J, Johansson AS, Rouhiainen A, Erlandsson-Harris H, Yang H, Tracey KJ, Rauvala H, Palmblad J, Andersson J, Treutiger CJ. Activation of human umbilical vein endothelial cells leads to relocation and release of high-mobility group box chromosomal protein 1 . Scand J Immunol 2004;60:566-573. [PubMed: 15584967]

46. Abeyama K, Stern DM, Ito Y, Kawahara K, Yoshimoto Y, Tanaka M, Uchimura T, Ida N, Yamazaki $\mathrm{Y}$, Yamada $\mathrm{S}$, et al. The N-terminal domain of thrombomodulin sequesters high-mobility group-B1 protein, a novel antiinflammatory mechanism. J Clin Invest 2005;115:1267-1274. [PubMed: 15841214]

47. Laszik ZG, Zhou XJ, Ferrell GL, Silva FG, Esmon CT. Down-regulation of endothelial expression of endothelial cell protein $\mathrm{C}$ receptor and thrombomodulin in coronary atherosclerosis. Am J Pathol 2001;159:797-802. [PubMed: 11549570]

48. Rouhiainen A, Imai S, Rauvala H, Parkkinen J. Occurrence of amphoterin (HMG1) as an endogenous protein of human platelets that is exported to the cell surface upon platelet activation. Thromb Haemost 2000;84:1087-1094. [PubMed: 11154118]

49. Hansson GK. Inflammation, atherosclerosis, and coronary artery disease. N Engl J Med 2005;352:1685-1695. [PubMed: 15843671]

50. Bradshaw G, Gutierrez A, Miyake JH, Davis KR, Li AC, Glass CK, Curtiss LK, Davis RA. Facilitated replacement of Kupffer cells expressing a paraoxonase-1 transgene is essential for ameliorating atherosclerosis in mice. Proc Natl Acad Sci USA 2005;102:11029-11034. [PubMed: 16043712]

51. Cipollone F, Iezzi A, Fazia M, Zucchelli M, Pini B, Cuccurullo C, De Cesare D, De Blasis G, Muraro $\mathrm{R}$, Bei R, et al. The receptor RAGE as a progression factor amplifying arachidonate-dependent inflammatory and proteolytic response in human atherosclerotic plaques: role of glycemic control. Circulation 2003;108:1070-1077. [PubMed: 12912808]

52. Park L, Raman KG, Lee KJ, Lu Y, Ferran LJ Jr, Chow WS, Stern D, Schmidt AM. Suppression of accelerated diabetic atherosclerosis by the soluble receptor for advanced glycation endproducts. Nat Med 1998;4:1025-1031. [PubMed: 9734395]

53. Bucciarelli LG, Wendt T, Qu W, Lu Y, Lalla E, Rong LL, Goova MT, Moser B, Kislinger T, Lee DC, et al. RAGE blockade stabilizes established atherosclerosis in diabetic apolipoprotein E-null mice. Circulation 2002;106:2827-2835. [PubMed: 12451010] 
54. Dybdahl B, Wahba A, Lien E, Flo TH, Waage A, Qureshi N, Sellevold OF, Espevik T, Sundan A. Inflammatory response after open heart surgery: release of heat-shock protein 70 and signaling through toll-like receptor-4. Circulation 2002;105:685-690. [PubMed: 11839622]

55. Woo YJ, Taylor MD, Cohen JE, Jayasankar V, Bish LT, Burdick J, Pirolli TJ, Berry MF, Hsu V, Grand T. Ethyl pyruvate preserves cardiac function and attenuates oxidative injury after prolonged myocardial ischemia. J Thorac Cardiovasc Surg 2004;127:1262-1269. [PubMed: 15115981]

56. Cheng TO. All teas are not created equal - The Chinese green tea and cardiovascular health. Int J Cardiol. 2005[Epub ahead of print]

57. Wang P. Andrenomedullin and cardiovascular responses in sepsis. Peptides 2001;22:1835-1840. [PubMed: 11754970]

58••. Palumbo R, Sampaolesi M, De Marchis F, Tonlorenzi R, Colombetti S, Mondino A, Cossu G, Bianchi ME. Extracellular HMGB1, a signal of tissue damage, induces mesoangioblast migration and proliferation. J Cell Biol 2004;164:441-449. [PubMed: 14744997]This is the first report suggesting that low levels of HMGB1 may be beneficial in tissue repair by attracting stem cells.

59. Limana F, Germani A, Zacheo A, Kajstura J, Di Carlo A, Borsellino G, Leoni O, Palumbo R, Battistini L, Rastaldo R, et al. Exogenous high-mobility group box 1 protein induces myocardial regeneration after infarction via enhanced cardiac C-Kit+ cell proliferation and differentiation. Circ Res 2005;97:e73-e83. [PubMed: 16166556] 


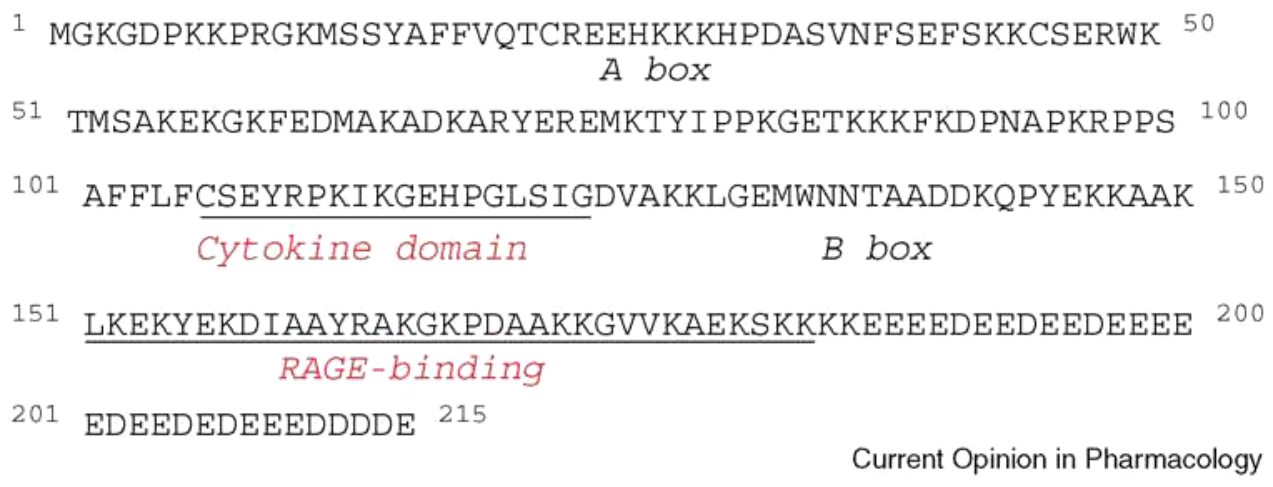

Current Opinion in Pharmacology

Figure 1.

Amino acid sequence of human HMGB1. The C-terminal portion of HMGB1 contains an acidic (aspartic acid [D] and glutamic acid [E]) tail, and the N-terminal portion of HMGB1 comprises two internal repeats of a positively charged domain of about 80 amino acids (termed 'HMG boxes') (shown by bold text). The cytokine-stimulating motif ('Cytokine domain', shown by underline) of HMGB1 does not overlap with its RAGE-binding site (shown by underline), implicating the potential involvement of other cell surface receptors for HMGB1-mediated inflammatory responses. 


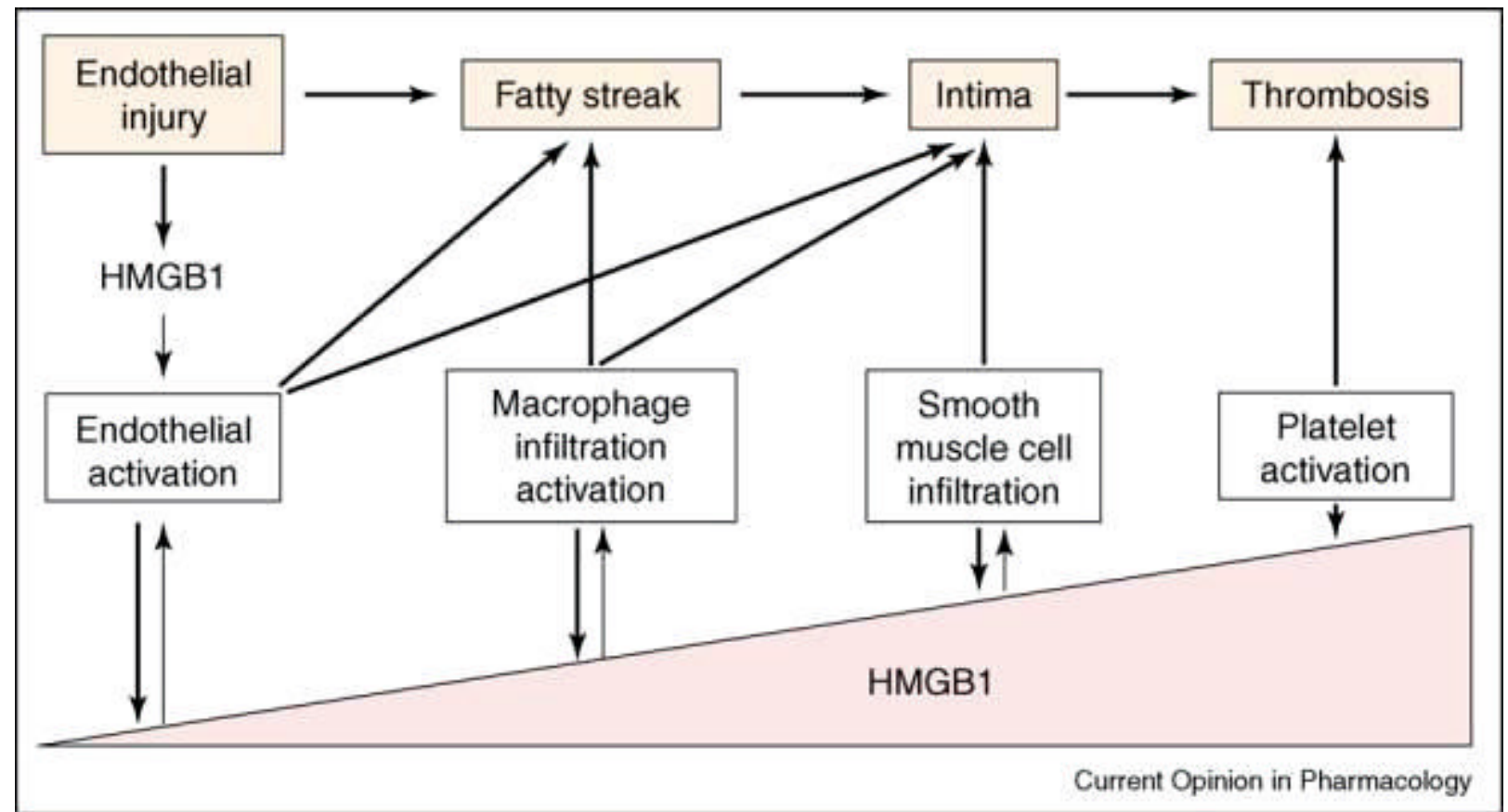

Figure 2.

Hypothetical roles of HMGB1 in the pathogenesis of atherosclosis. Atherosclerosis is characterized by focal thickenings of the innermost layer of the artery, the intima, which contains vascular endothelial, inflammatory (e.g. macrophages) and smooth muscle cells. It begins with an injury to the endothelial wall of the artery, and is followed by macrophage infiltration, and fatty streak accumulation. The uncontrolled growth of intima can subsequently lead to thrombus formation, followed by ischemic injury and myocardial infarction. In response to primary endothelial cell injury, HMGB1 may be passively released, which initiates a pronounced inflammatory response driven by endothelial cells as well as infiltrated innate immune cells. The injury-elicited inflammatory response could contribute to the pathogenesis of cardiovascular diseases. The pink area denotes the extracellular levels of HMGB1. 